\title{
Wharton's Jelly-derived Mesenchymal Stem Cells and Polycaprolactone/Hydroxyapatite (PCL/HA) Scaffold for Bone Tissue Engineering
}

\author{
Mohammd Rahmani', Mohammad Ghasem Golmohammadi', Asadollah Asadi ${ }^{3}$, \\ Amir Delavar ${ }^{4}$ Farah Farokhi ${ }^{1}$ \\ Original \\ Article \\ ${ }^{1}$ Department of Biology, Faculty of Sciences, Urmia University, Urmia, Iran \\ ${ }^{2}$ Department of Anatomy, Laboratory of Embryology and Stem cells, Faculty of Medicine, \\ Ardabil University of Medical Sciences, Ardabil, Iran \\ ${ }^{3}$ Department of Biology, Faculty of Science, University of Mohaghegh Ardabili, Ardabil, Iran \\ ${ }^{4}$ Department of Anatomy and cell biology, Faculty of medicine, Mashhad University of Medical \\ Sciences, Mashhad, Iran.
}

\begin{abstract}
Background: Polycaprolactone (PCL) is a suitable polymer in the field of drug delivery and tissue engineering scaffolds. Aim of Work: This study aimed to design a Polycaprolactone /Nano hydroxyapatite (PCL/nHA10\%) hybrid nanofiber scaffold and evaluate differentiation of Wharton's jelly-derived mesenchymal stem cells (WJ-MSCs) to osteogenic lineage on scaffolds for bone tissue engineering.

Materials and Methods: In this study, PCL/nHA(10\%) composite polymeric nano scaffolds were prepared by electrospinning. Mesenchymal stem cells were isolated from the Warton's Jelly and cultured in the PCL/nHA 10\% scaffold. Biocompatibility of scaffolds was confirmed by MTT assay. Characterization of umbilical cord mesencymal stem cells were performed using flow cytometry. The morphological and cell adhesion characteristics of mesenchymal stem cells (MSCs) on the scaffolds were performed using scanning electron microscopy (SEM) imaging. Finally, the cells were treated with osteogenic differentiation medium for 21 days to investigate their differentiation potential on the scaffolds and then differentiated cells were stained with alizarin red and von Kossa stains.

Results: The largest pore size of PCL/nHA (10\%) nanofibers was about $22 \mu \mathrm{m}$. The culture of WJ-MSCs on the scaffolds showed that the addition of nHA 10\% to PCL scaffold caused further attachment and proliferation of the cells. The stained mineral deposit scaffold with alizarin red and von Kossa were also compared. In both types of staining, nano-composite scaffold showed higher calcium deposits.

Conclusion: The results showed that the PCL/nHA 10\% scaffolds for bone tissue engineering is a good choice, and can be used for bone tissue repair.
\end{abstract}

Received: 17 September 2019, Accepted: 21 October 2019

Key Words: Bone tissue; hydroxyapatite; mesenchymal stem cells; polycaprolactone.

Corresponding Author: Farah Farokhi, PhD, Department of Biology, Faculty of Sciences, Urmia University, Urmia, Iran, Tel.: 09143460715, E-mail: f.farokhi1338@gmail.com

ISSN: 1110-0559, Vol. 43, No.2

\section{INTRODUCTION}

Every year, millions of people suffer from bone defects as a result of injuries or bone diseases. The treatment process of the body in dealing with fractures and large defects may not function properly and thus, bone grafting is required. Therefore, given that bone has a high potential for proliferation, it is suitable for tissue engineering ${ }^{[1]}$. The purpose of bone tissue engineering is to provide a method for the treatment of large bone defects. In bone tissue engineering, the scaffold must have ossification conditions and provide a good culture medium for osteoblast cells ${ }^{[2]}$. Ideal materials for scaffolding should be fabricated effortlessly of the desired biomaterials that imitate the structure and properties of the bone extracellular matrix ${ }^{[3]}$. Therefore, to improve connectivity, cell colonization, and increase the efficiency of cultivation, the use of an appropriate scaffold for bone tissue engineering is necessary; where in the 3-D culture of cell morphology is similar to the in vivo condition, resulting in better cell interactions ${ }^{[4]}$.

Stem cells are good sources for tissue engineering applications. In fact, these cells have become an interesting therapeutic tool because of their unique features including the ability to separate easily, broad cultures, high mitotic 
division, and differentiation into specialized cell types ${ }^{[5]}$. The umbilical cord is composed of a special embryonic mucous tissue called Wharton's jelly, lying between the amniotic epithelium covering and the umbilical vessels ${ }^{[6]}$. Stromal cells of Wharton's jelly have been shown to possess multipotent properties, and they can differentiate into different types of cells (e.g., bone cells) in the culture medium $^{[7]}$. These cells also secrete growth factors that can affect the proliferation and growth of other cells ${ }^{[8]}$.

Composites of polymers and bioactive ceramics are a perfect combination for building bone tissue engineering scaffolds. The 3-D porous composite scaffolds can induce the ingrowth of a cell to a favorable shape, and may simplify the vascularization of new generated tissue ${ }^{[9]}$.

Also, poly-caprolactone (PCL) has been widely studied in tissue engineering because of its compatibility with most medications and its solubility in most organic solvents ${ }^{[10]}$. Despite the inherent biocompatibility and biodegradability of polymer PCL in the use of this material in prostheses, implants, and tissue engineering matrices, a hydrophobic problem occurs that may result in the production of external reactions, including inflammation, infection, and internal lesions in the body. In fact, the lack of functional groups that directly bind to cell ligands is a problem related to PCL use ${ }^{[11]}$.

Hydroxyapatite (HA) has been used as an implant for biomedical applications and bone remodeling, especially due to its biocompatibility, biodegradability, and bony properties. In fact, HA provides an active level for living tissue, and during ossification it has the ability to create cell and tissue junctions. Thus, much attention has been focused recently on polymer/HA composites ${ }^{[12]}$.

The aim of this study was to build a biocompatible scaffold for the restoration of bone defects. The electrospinning method was used to fabricate polycaprolactone / hydroxyapatite (PCL/nHA 10\%) composite scaffolds. Furthermore, the pore structure and morphology of the prepared scaffolds, cell attachment, growth capacity, and differentiation of WJ-MSCs into osteoblasts were investigated. Therefore in this study, we have investigated the amount of distinction of Wharton's jelly mesenchymal stem cells (WJ-MSCs) on the scaffold using $10 \%$ hydroxyapatite in the manufacturing of scaffolds, but in similar studies, the amount of hydroxyapatite used is unknown and the sources of the stem cells used are different.

\section{MATERIALS AND METHODS}

\subsection{Preparation of PCL / HA Scaffolds}

The scaffolds were fabricated via the electrospinning $\operatorname{method}^{[13]}$. The materials needed to manufacture nanofibrous scaffolds include: $\mathrm{Pcl}$ (intrinsic viscosity $=1.0$ dl g-1, Sigma-Aldrich), Chloroform (Merck, Germany), DMF (N, N-dimethyl formamide, Merck, Germany), and nHA particles (Merck, Germany). To make the scaffold, the PCL/nHA polymer was dissolved in Chloroform and DMF solvent (the ratio of PCL and HA was 10:1 in PCL/HA polymer solution). The polymer solution was transferred into the electrospinning machine syringe, activated by an injection pump and fed through the needle, which was kept at a high DC voltage $(20 \mathrm{kV})$ and the interval of the electric field was fixed at $20 \mathrm{~cm}$. Also, to overcome the hydrophobicity of PCL polymer and to increase the percentage of connection of the cell to the scaffold using the technique of plasma treatment technique, the surface charateristics of the scafold was changed due to the increase of cellular concentration. For this purpose, the scaffold was treated by plasma in reactive $\mathrm{O} 2$ plasma for $4 \mathrm{~min}^{[14]}$.

\subsection{Evaluation of Scaffold Morphology}

Pore size distribution in porous scaffolds was investigated using Image $\mathrm{J}$ software. The surface morphology of the scaffolds and cell scaffold constructs were examined by SEM. For this purpose, SEM images were prepared from the scaffold and the results were presented in graph. Also, to investigate the morphological differences of PCL/nHA electrospinning scaffolds with the single structure of PCL and HA, scanning electron microscope (LEO1430VP) images were prepared. For this purpose, the scaffold was cut into small pieces and then sputter-coated by gold. Finally, it was placed at the place of the device and the necessary images were taken. The cell loaded scaffold specimens from the day-3 culture were prepared for the SEM. For this purpose, the MSCs-loaded scaffolds were fixed in a 4\% paraformaldehyde (SigmaAldrich) solution at $30{ }^{\circ} \mathrm{C}$ for $45 \mathrm{~min}$, followed by washing with $\mathrm{dH}_{2} \mathrm{O}$, drying and coating with gold. The specimens were examined with SEM (LEO1430VP) at an acceleration voltage of $10 \mathrm{kV}$.

\subsection{Study the Water Absorption Property of PCL/HA Scaffolds}

The PCL/nHA scaffold degradation study was performed in a phosphate buffer solution in a laboratory environment, and at $\mathrm{pH}$ 7.4. The 24 scaffolds measuring $1 \times 1 \mathrm{~cm}^{2}\left(\mathrm{w}_{\mathrm{o}}\right)$ were weighted. After placing the samples in ethanol, they were exposed to ultraviolet radiation. Then they were placed in the buffer and taken out every five days. After measuring the buffer $\mathrm{pH}$, the surface water samples were taken with filter paper and the samples were weighted. The water absorption $\left(\mathrm{W}_{\mathrm{A}}\right)$ percentage was calculated and plotted using the following equation ${ }^{[15]}$.

$$
\mathrm{W}_{\mathrm{A}} \%=\left(\mathrm{w}_{\mathrm{a}}-\mathrm{w}_{\mathrm{o}}\right) / \mathrm{w}_{\mathrm{o}} \times 100
$$

Where $\mathrm{W}_{\mathrm{a}}=$ soaked weight, $\mathrm{W}_{\mathrm{o}}=$ dry weight of the scaffolds.

\subsection{Scaffold Porosity}

The porosity of the scaffold was measured by the Archimedes principle. According to this principle, the total porosity, including all the pores in the scaffold, is obtained from the ratio of the volume of cavities in the scaffold to the total volume of the scaffold and are often expressed as percentages. Ethanol and water were selected as fluids. 
Two beakers were filled with $80 \mathrm{ml}(\mathrm{V})$ of ethanol and water and weighted ( $\mathrm{mw}$ and me). Then the scaffold was immersed first in water and then in ethanol while being placed on a scale. The apparent weight of the scaffold was measured in water and in ethanol. The total volume of the scaffold $\left(\mathrm{V}_{1}\right)$ was obtained by using the product of length (a), width (b) and thickness (c) of the scaffold. The volume of the cavities $\left(\mathrm{V}_{2}\right)$ was calculated by the third equation. Finally, the porosity percentage $(\varepsilon)$ of the scaffold can be calculated by placing the numbers obtained in equation 4. All steps were carried out at $25^{\circ} \mathrm{C}$. According to the Archimedes principle, porosity of the scaffold was theoretically calculated using the following equation:

$$
\begin{aligned}
& \rho_{1}=\mathrm{m}_{\mathrm{w}} / \mathrm{v}, \rho_{2}=\mathrm{m}_{\mathrm{e}} / \mathrm{v} \\
& \mathrm{v}_{1}=\mathrm{a} \times \mathrm{b} \times \mathrm{c} \\
& \mathrm{v}_{2}=\left(\mathrm{w}_{1}-\mathrm{w}_{2}\right) /\left(\rho_{2}-\rho_{1}\right) \\
& \text { Porosity }(\%)=\left(\mathrm{v}_{1}-\mathrm{v}_{2}\right) / \mathrm{v}_{1} \times 100
\end{aligned}
$$

Where, $\rho_{1}$ is the density of water, $\rho_{2}$ is the density of ethanol $\mathrm{a}, \mathrm{b}$ and $\mathrm{c}$ are the length, width and thickness of the scaffold. $W_{1}$ is the water saturated wet mass of the scaffold and $\mathrm{W}_{2}$ is the ethanol saturated wet mass of the scaffold ${ }^{[16]}$.

\subsection{Attenuated Total Reflection-Fourier-Transform Infrared Spectroscopy (ATR-FTIR)}

Structural characterization and functional group identification was accomplished using the attenuated total reflection Fourier transform infrared spectroscopy (wave-number range $4000 \mathrm{~cm}-1$ to $400 \mathrm{~cm}-1$ with $8 \mathrm{~cm}-1$ spectral resolution $)^{[17]}$.

\subsection{Isolation of WJ-MSCs from the Umbilical Cord}

Infants' umbilical cords were obtained from Ardabil Arta Hospital after parental permission was given and taken to the lab in sterile conditions, inside saline solution. All the experimental protocols were approved by the Ethics Committee of Urmia University (AECVU-196-2019). In brief, to remove cord blood, fresh umbilical cords were taken and rinsed twice using Hanks' balanced salt solution (HBSS), (Merck, Germany). The washed umbilical cords were cut into $1 \mathrm{~cm}$ pieces and Wharton's Jelly was scratched out carefully and floated in Dulbecco's modified Eagle's medium with low glucose (DMEM-LG, Bio-IDEL) containing 10\% FBS (GIBCO), 5\% penicillin and streptomycin (GIBCO). The pieces of the cord were subsequently incubated at $37 \circ \mathrm{C}$ in humid air with $5 \% \mathrm{CO}_{2}$. The medium was replaced every three days after the initial plating, and non-adherent cells were removed by washing. Fibroblast-like cells appeared after 10 days of cultures ${ }^{[18]}$.

\subsection{Flow cytometry analysis}

\section{anti-CD90}

To confirm the extraction of mesenchymal stem cells, analysis of flow cytometry was performed. Finally, after the third passage of cells, 105-106 cells $/ \mathrm{ml}$ were added to each vial. Vials containing the cells were blocked with
$3 \% \mathrm{BSA}$ in $1 \mathrm{ml}$ PBS for 30 minutes and then they were incubated with an appropriate concentration of anti CD45, CD90 and CD105 antibodies (Rabbit anti- CD45, CD90 and CD105, Abcam, England) for $45 \mathrm{~min}$. The secondary antibody (goat anti-rabbit FITC, Abcam, England) was added and incubated for $45 \mathrm{~min}$ at $37^{\circ} \mathrm{C}$. Then the suspension was centrifuged and finally, cell suspension with $200 \mu \mathrm{l}$ paraformaldehyde (4\%) was combined and flow cytometric analysis was performed on them ${ }^{[19]}$.

\subsection{Cell Culture on the Scaffold}

After being subcultured for the third passage, the cells were trypsinized and mixed with DMEMLG. The nanofibrous scaffolds (PCL/nHA) were carefully cut into small rectangles and were then sterilized with $70 \%$ ethanol overnight and ultraviolet light for $2 \mathrm{~h}$ and then rinsed three times with PBS before being placed in 24-well culture plates. Next they were put into $24-w e l l$ plates and immersed in PBS for $3 \mathrm{~h}$. Afterwards, a cell suspension with a cell density of $5 \times 104$ cells $\mathrm{mL}-1$ (cell per $\mathrm{ml}$ ) was placed on the scaffold with a micropipette and allowed to adhere to the surface within $3 \mathrm{~h}$ before adding the culture medium. Cells were grown in the 24 -well plate. The cell culture medium was replaced every two days ${ }^{[20]}$.

\subsection{Examination of Cytotoxicity with MTT Assay}

The viability and proliferation of WJ-MSCs were determined by 3-(4, 5-Dimethylthiazol-2-yl)-2, 5 Diphenyltetrazolium Bromide (MTT) assay. The assay reflected the activity of a mitochondrial dehydrogenase that transforms light yellow MTT into dark blue formazan. The intensity of the resulting color was determined photometrically. The cell-seeded scaffolds were maintained at $37^{\circ} \mathrm{C}$ under $5 \% \mathrm{CO}_{2}$ for different time periods. During the test, the culture medium in the disks was removed and rinsed by PBS three times and then $200 \mu$ RPMI1640 (BioIDEL) was added to each well. Next, $20 \mu$ of MTT solution $(5 \mathrm{mg} / \mathrm{mL})$ was freshly added to the culture wells and incubated at $37^{\circ} \mathrm{C}$ and $5 \% \mathrm{CO}_{2}$ for $4 \mathrm{~h}$. The upper medium was removed carefully and the intracellular formazan was solubilized by adding $100 \mu \mathrm{L}$ of DMSO (Merck, Germany) to each well, incubating at $37{ }^{\circ} \mathrm{C}$ and $5 \% \mathrm{CO}_{2}$ for $10 \mathrm{~min}$. The absorbance of the produced formazan was measured at 570nm with an ELIZA reader (URIT-660, China). All experiments were performed in duplicate, and the relative cell viability was expressed relative to the control cells. The experiment was repeated three times, the results of which are presented as means ${ }^{[21]}$.

\subsection{Differentiation of WJ-MSCs into Osteoblasts on Scaffolds}

The third passage of WJ-MSCs was used for the seeding into the PCL/nHA scaffolds. Prior to seeding, the scaffolds were sterilized with $70 \%$ ethanol overnight and ultraviolet light for $2 \mathrm{~h}$ and then placed into 24-well cell culture plates and treated with PBS. The well-plate was left in the incubator at $37 \circ \mathrm{C}$ with $5 \% \mathrm{CO}_{2}$ for $3 \mathrm{~h}$. A cell suspension $(20 \mu \mathrm{L})$ with a cell density of $2 \times 105$ cells mL-1 
was seeded evenly into the scaffolds with a micro-pipette. Osteogenesis medium (growth medium with the addition of $10 \mathrm{nM}$ dexamethasone, $50 \mu \mathrm{g} / \mathrm{ml}$ ascorbic acid-2phosphates and $10 \mathrm{mM}$-glycerophosphate, Bio-IDEL) was applied 24 hours after plating. The medium was replaced every two days. Osteogenesis was assessed on day $21^{[22]}$.

\subsection{Alizarin Red and Von Kossa Staining}

To confirm the presence of differentiated mesenchymal cells, it was necessary to stain the cells after culture with dyes used specifically for bone cells (day 21). The staining was carried out on days 7, 14 and 21 . In brief, the cell-nanofibrous scaffolds were fixed in $4 \%$ formaldehyde for $45 \mathrm{~min}$ followed by staining with alizarin red (Merck, Germany) for $8 \mathrm{~min}$. After washing five times with distilled water, they were examined under a microscope ${ }^{[23]}$. Von Kossa stain was used to quantify mineralization in cell culture and tissue sections. Briefly, the cell scaffold was washed with PBS and fixed in 4\% PFA solution for 45 min and cell-nanofibrous scaffolds were stained with $1 \%$ silver nitrate (Merck, Germany) for 45 min under ultraviolet light, followed by $2.5 \%$ sodium thiosulfate (Merck, Germany) for $5 \mathrm{~min}$. Then cell-nanofibrous scaffolds were rinsed three times with distilled water checked by an inverse microscope and photographed ${ }^{[24]}$.

\subsection{Statistical Analysis}

Data are presented as mean \pm SEM. Comparisons were performed by one way ANOVA followed by Tukey's posthoc test using the SPSS 18.0 software (SPSS Inc., Chicago, IL, USA). $P<0.05$ was considered statistically significant.

\section{RESULTS}

\subsection{Scaffold Surface Morphology Characterization}

Electron micrographs prepared from PCL/nHA scaffold surfaces are illustrated in (Figure 1). Nanofiber scaffold has a porous structure with interconnected pores and uniform smooth fibers. PCL/nHA scaffold images showed the dispersion of HA particles on PCL fibers. Replacing HA particles on the PCL scaffold led to a rugged and larger surface where it increases connectivity and broadens the growth of mesenchymal stem cells in the scaffold surface (Figure 1).

\subsection{Distribution of Scaffold Pore Size}

(Figure 2) shows distribution of pores in the PCL/nHA Scaffold. The graphs show that the pore size in the composite scaffold is large and according to the data, the largest scaffold pore size is about $22 \mu \mathrm{m}$.

\subsection{Water Absorption Properties of PCL/nHA Scaffolds}

The results are presented in (Figure 3) The water absorption capacity of the scaffolds ranged from $150 \%$ to $280 \%$, which indicated that the pore structure and composition of the scaffold was the mechanism for water uptake capacity. Hence, the composite scaffolds induced higher water uptake in comparison with the pure PCL scaffold. However, from the tenth day onwards, the water absorption capacity began to decrease in the scaffold because of the presence of HA particles at the surface of the PCL/nHA scaffold.

\subsection{Porosity and Scaffold Morphology}

According to the Archimedes principle, porosity of the scaffold is shown in (Table 1). In addition, the morphology of the nanofibrous scaffold was illustrated by SEM micrographs. (Figure 1) shows a well fabricated nano/fibrous porous PCL/nHA matrix, similar to those of natural ECM. The nano-fiber exhibits a large surface area, which benefits the good in-growth of cells. Also, (Figure 1) shows the MSCs attachment and growth on PCL/nHA electrospun membranes on day 3 of seeding. From the SEM micrographs it can be observed that the cells adhered and spread on the surface of the polymer nanofibers. This is evidence for the cells good interaction and integration with the surrounding fibers.

\subsection{ATR-FTIR}

Analysis of ATR-FTIR spectra for nanocomposite is shown in (Figure 4). The absorption peaks at 570, 600 and $1040 \mathrm{~cm}-1$ correspond to $-\mathrm{PO} 4$ group stretching. The peak at $1723 \mathrm{~cm}^{-1}$ corresponds to $\mathrm{O}-\mathrm{C}=\mathrm{O}$ group stretching in PCL. In addition, the peaks at $1360-1465 \mathrm{~cm}^{-1}$ corresponds to $\mathrm{CH}_{2}$ group in hydroxyapatite and the peaks 2930 and $3400 \mathrm{~cm}^{-1}$ are associated with $\mathrm{C}-\mathrm{H}$ and $\mathrm{OH}$ group stretching, respectively.

\subsection{Isolation and Identification of WJ-MSCs}

During the primary culture, WJ-MSCs adhered on the flask surface and the cells presented a small population of single cells with spindle shapes. Also, in the next steps, the cells introduced a population of fibroblast-like morphology (Figure 5).

\subsection{Flow Cytometry Analysis}

The results are presented in (Figure 6). Flow cytometric analysis showed that the percentages of CD90 and CD105 expression are 94\% and 90\% respectively, and the percentage expression of CD 45 was $2 \%$.

\subsection{Scaffold Morphology and Cell Culture on Scaffold}

The morphology of the nanofibrous scaffold was illustrated by SEM micrographs. (Figure 1) shows a well fabricated nano/fibrous porous PCL/ nHA matrix, similar to those of natural ECM. The nano-fiber exhibits a large surface area, which benefits the good in-growth of cells. Moreover, (Figure 1) shows the MSCs attachment and growth on PCL/ nHA electrospun membranes on day 3 of seeding. From the SEM micrographs, it can be observed that the cells adhered and spread on the surface of the polymer nanofibers. This is evidence of the cells good interaction and integration with the surrounding fibers. 


\subsection{MTT assay}

After cell culturing for 3, 5, and 7 days, the viability and proliferation of fibroblast cells were determined by MTT assay. The test showed that more viable cells existed in scaffolds a week after culture, making them quite suitable for MSCs growth. After day-7 of the culture, the value of absorbance was higher than that of the others days. There is no significant difference between different groups. However, there is a significant difference between the different days $(P<0.05)$. The Comparison of results between days 3,5 , and 7 showed that on day 7 the percentage of viability increased significantly compared to the days 3 and 5. This indicates that the MSCs showed much better viability on the PCL/nHA scaffold than the control cells (Figure 7).

\subsection{Alizarin Red and Von Kossa Staining}

The alizarin red and von Kossa staining was used to indicate the process of transformation of WJ-MSCs cells
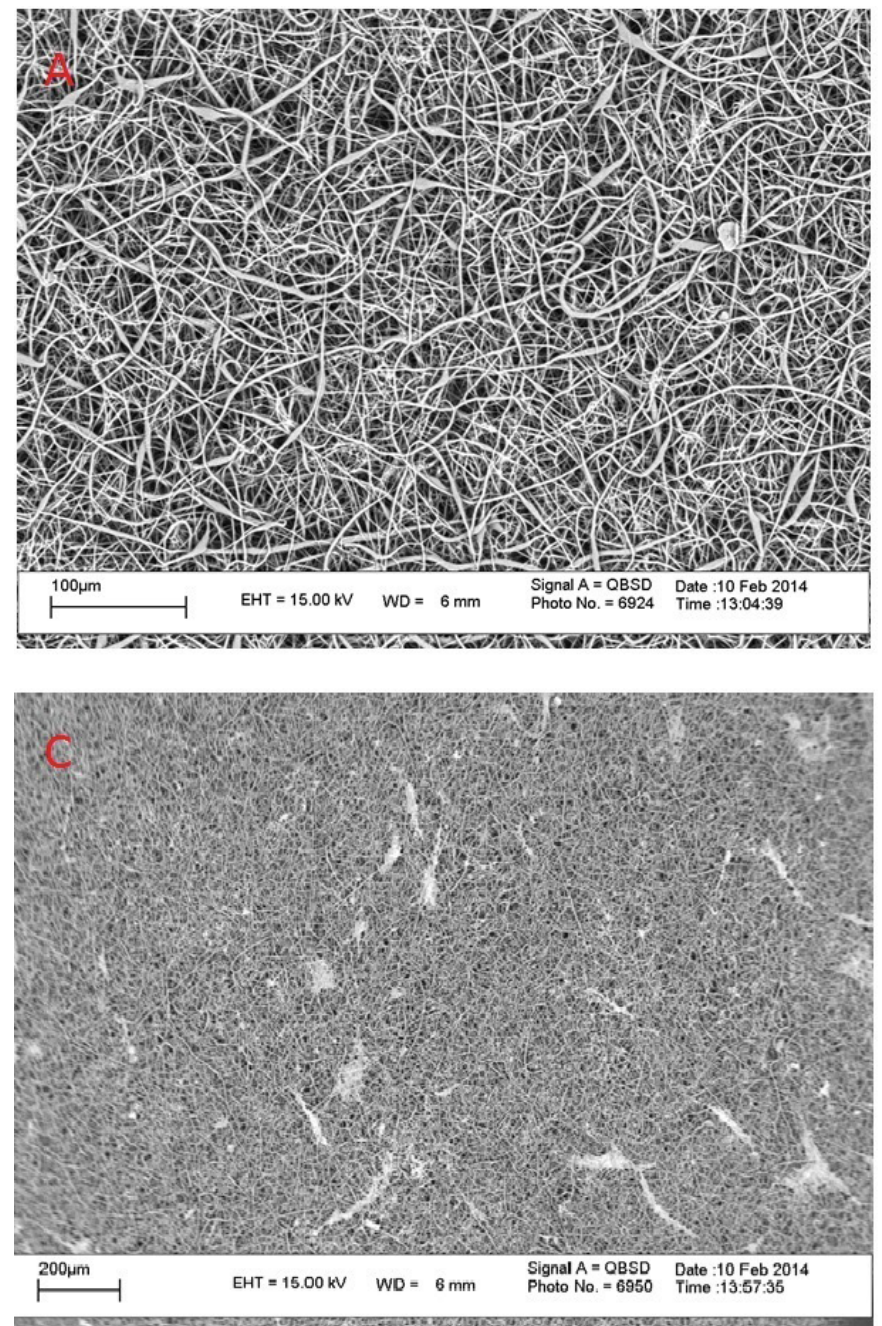

to osteoblasts and mineralization of scaffolds leading to the formation of bone. To analyse the mineralization capability of MSCs, the cells from the second passage were seeded on the PCL/nHA scaffold, and cultured for 21 days in the osteogenic medium. After 7-14, and 21 days of induction, the differentiated cells were assessed by staining with alizarin red and von Kossa. At the end of that time, the formation of mineral nodules in cultures on PCL/nHA was assessed by alizarin red and von Kossa staining. The differentiation of human mesenchymal stem cells seeded in PCL/nHA nanofiber scaffolds are shown in (Figure $8 \mathrm{~A}$ and $\mathrm{C}$ ). The WJ-MSCs cultured in PCL/nHA without osteogenic differentiation showed negative staining to alizarin red and von Kossa. (Figure 8) show seeded WJ-MSCs in the PCL/nHA scaffold treated with the osteogenic medium. The images show positive staining to alizarin red and von Kossa. The result suggests that WJ-MSCs differentiates into osteogenic cells with the presence of mineral deposition.
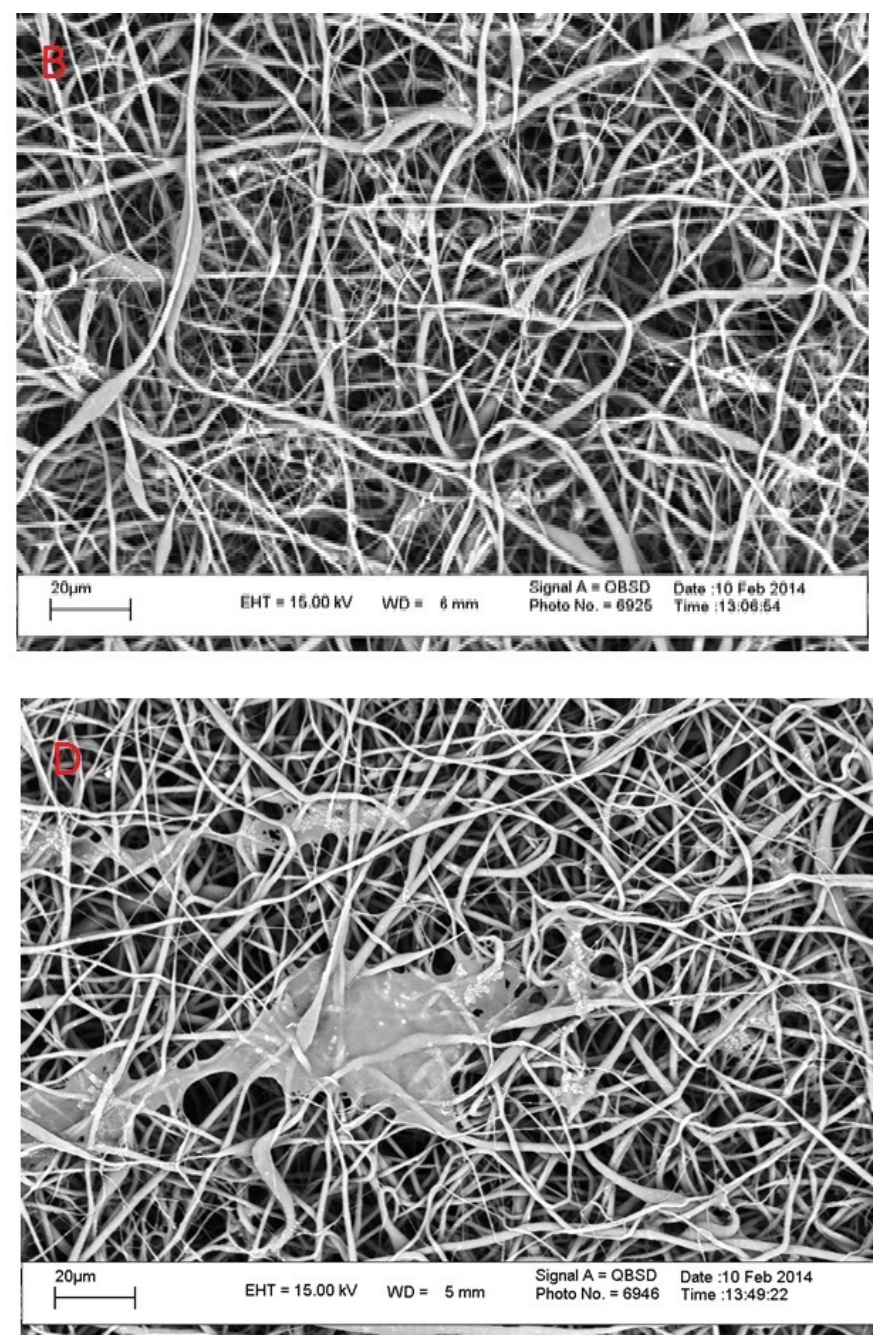

Fig. 1: SEM image of (A-B) PCL/nHA scaffold surface, scale bare is 100 and $20 \mu \mathrm{m}$ respectively. (C) PCL/nHA scaffold, scale bare is $200 \mu \mathrm{m}$. (D) Cell morphology of WJ-MSCs on the scaffold (three days after seeding). Scale bar is $20 \mu \mathrm{m}$. 

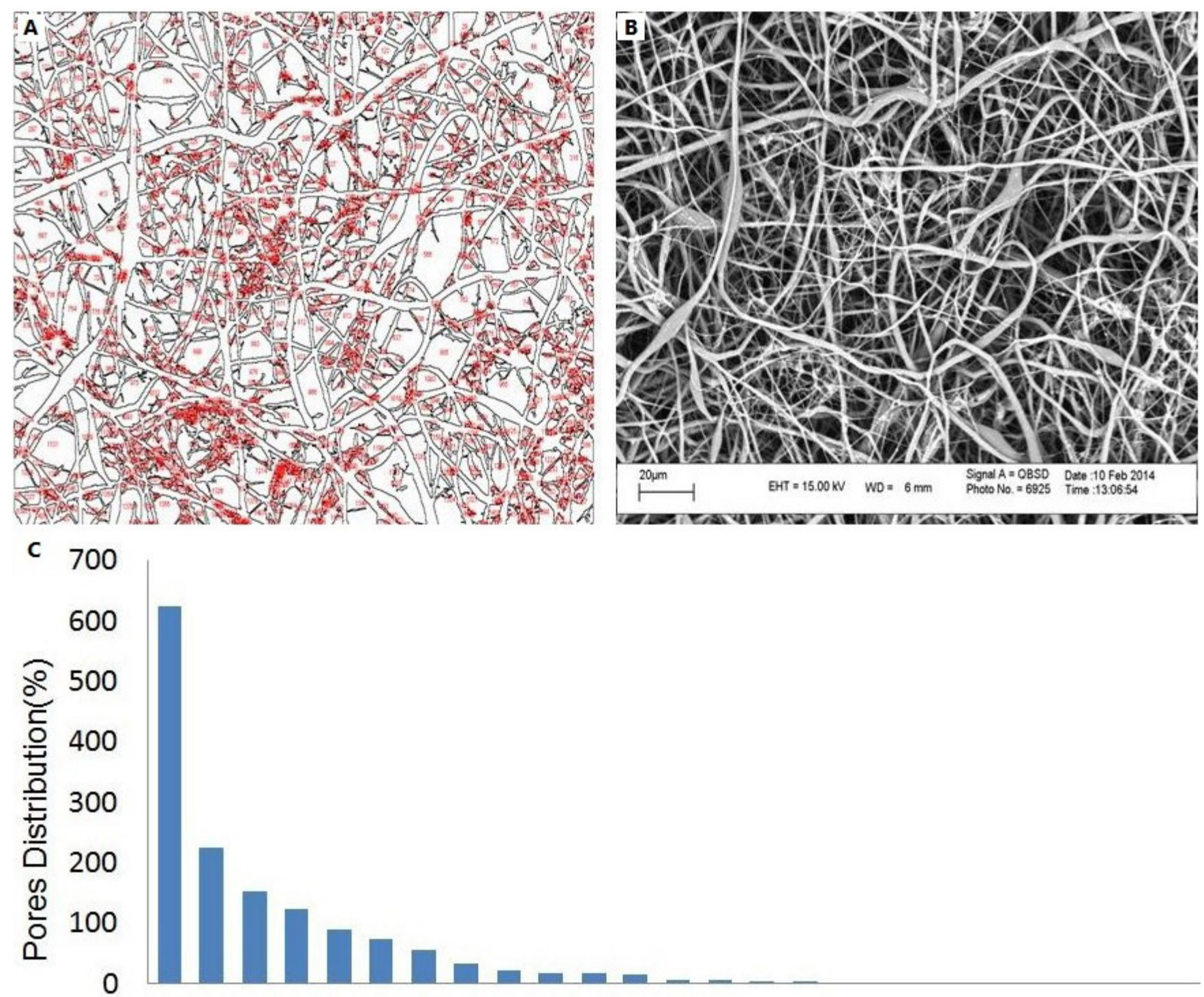

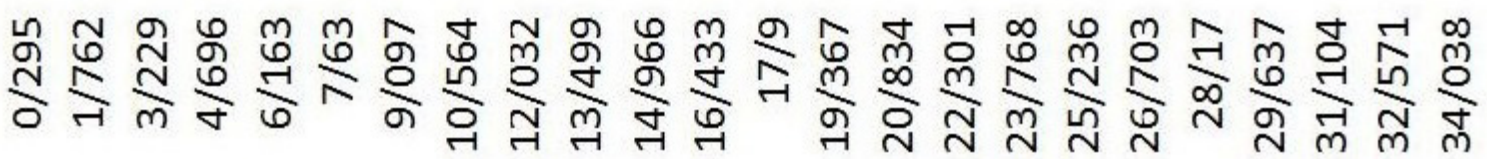

Pore size $(\mu \mathrm{m})$

Fig. 2: Image of the distribution of pores in the PCL/nHA Scaffold (A) Graphical image of pore position, (B) SEM image $\times 3000$ (C) Pore distribution diagram 


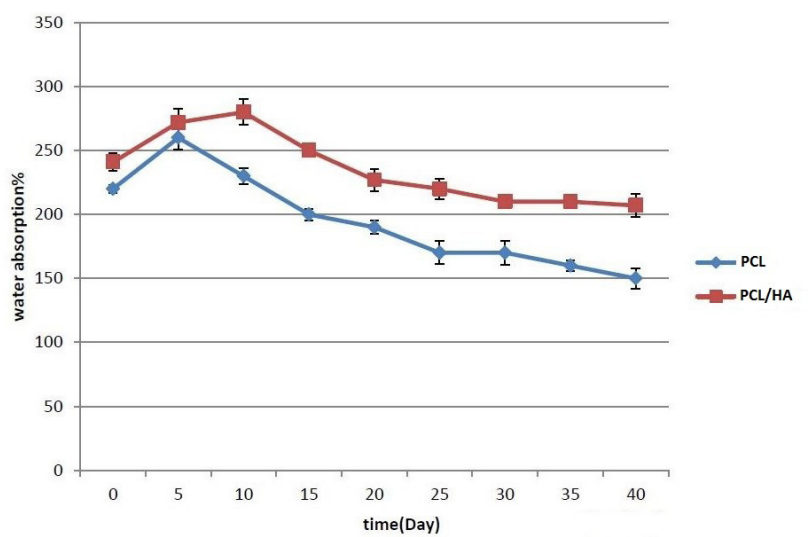

Fig. 3: Water absorption capacity of the PCL and PCL/HA scaffolds at different immersion times
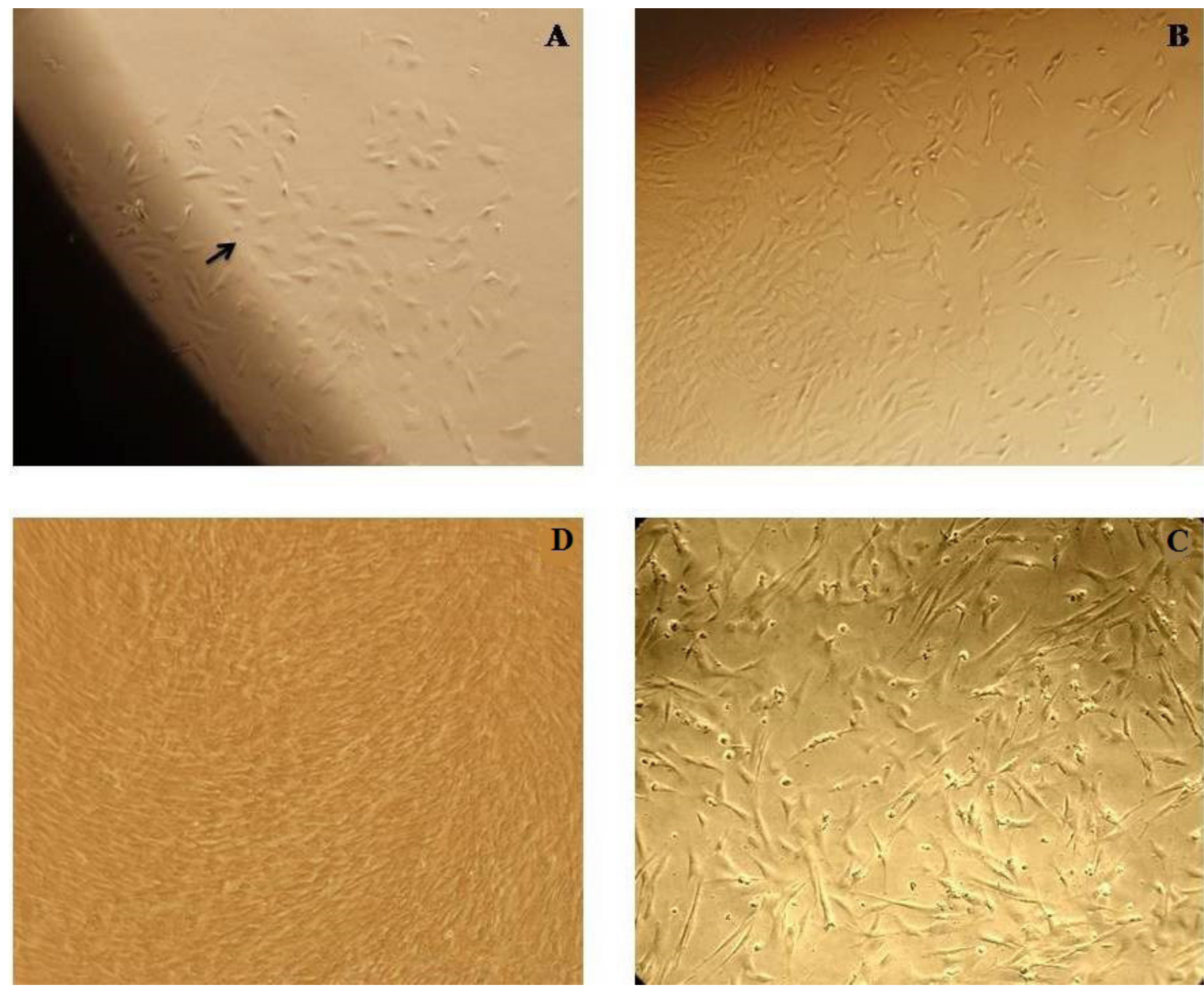

Fig. 5: Adhered cells in primary cultures of WJ-MSCs. The morphology and growth of cells withan MSC like phenotype after (A) growth of CELL buds from Wharton's Jelly, (B) the shape of a fibroblast like a Wharton's Jelly cell, (C) first passage, (D) third passage. (Photos provided by inverted microscope with original magnification, $\times 200$ for both panels) 

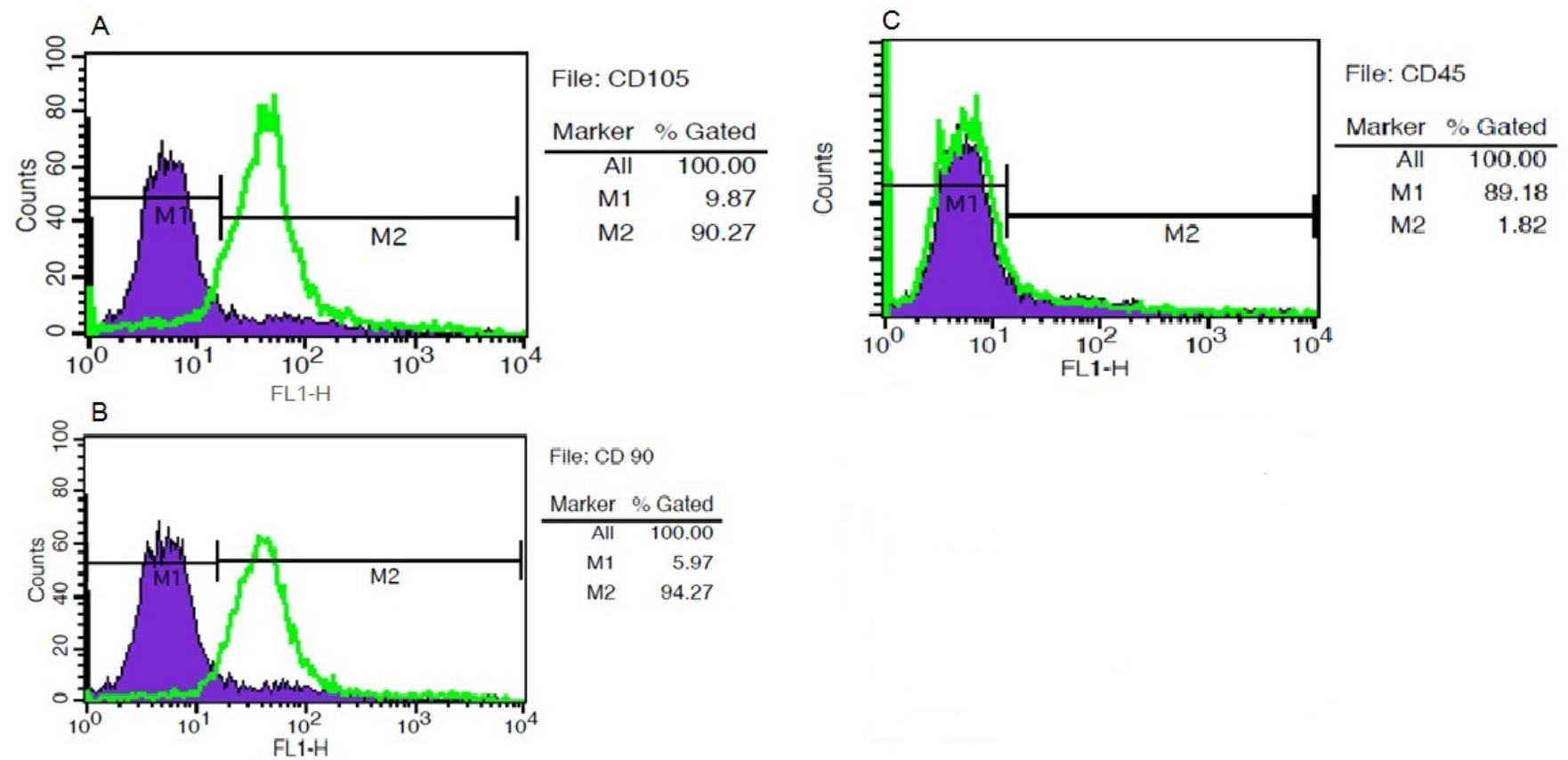

Fig. 6: Detection of surface antigens of WJ-MSCs with flow cytometry. A. CD105 in WJ-MSCs. B. CD90 in WJ-MSCs. C. CD45 in WJ-MSCs

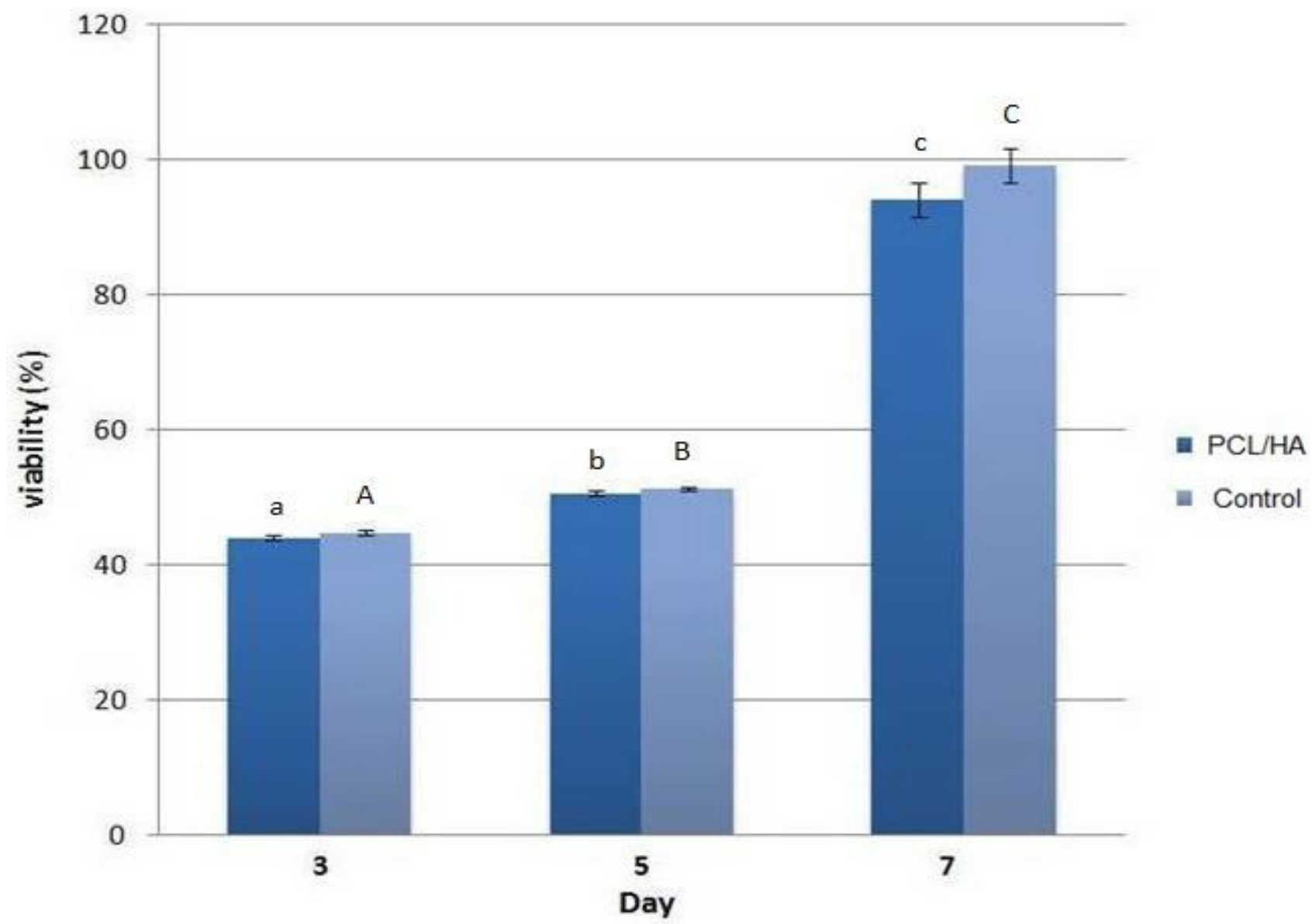

Fig. 7: MTT-tetrazolium assay of WJ-MSCs cultured in PCL/ HA scaffold for different days. Formosan absorbance is expressed as a function of scaffolds. (Error bars represent standard deviation) 


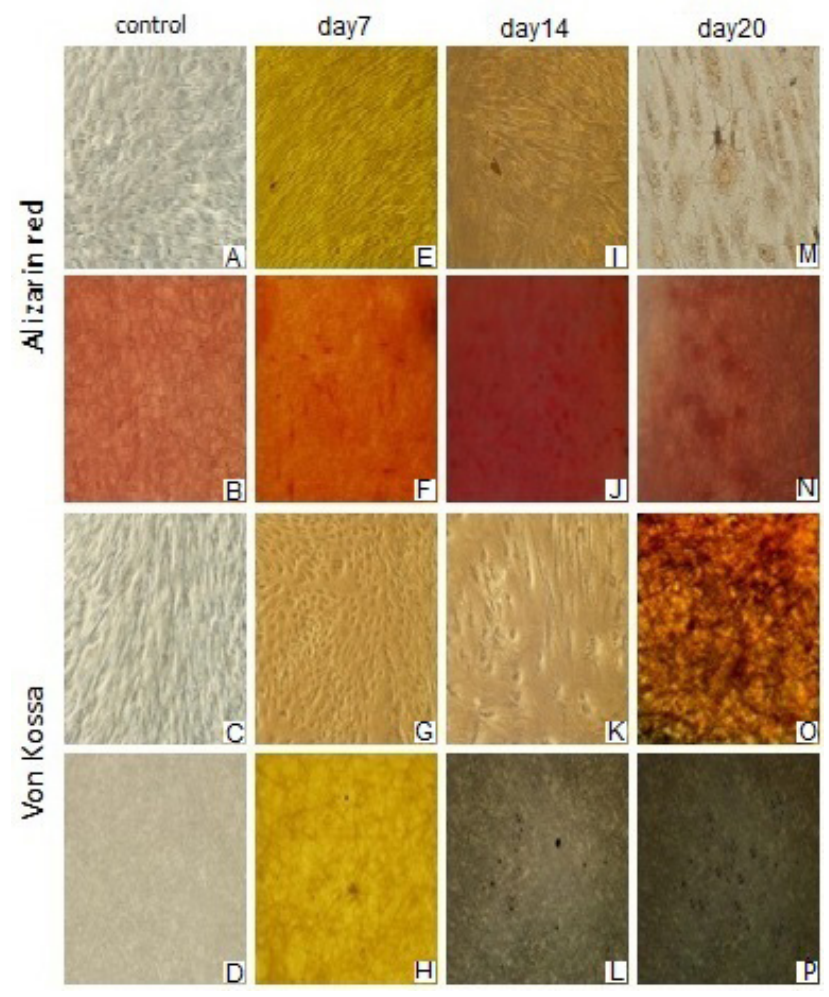

Fig. 8: Morphologies, alizarin red S and von Kossa staining of cultured WJ-MSCs. (Photos provided by inverted microscope with original magnification, $\times 200$, for all panels)

Table 1: Scaffold Porosity Measurement Results

\begin{tabular}{cc}
\hline Parameter & PCL / HA Scaffold \\
\hline V1 & $0 / 06371$ \\
V2 & $0 / 00446$ \\
W1 & $0 / 03909$ \\
W2 & $0 / 03040$ \\
Porosity (\%) & $\% 93$ \\
\hline
\end{tabular}

\section{DISCUSSION}

A challenge with using scaffolds is the absence of active functional groups that directly attach to cell ligands. In the present study, to overcome this problem, plasma treatment was performed on the scaffold surface. Plasma treatment is much easier than other chemical methods to improve the surface of the PCL scaffold ${ }^{[25]}$. This treatment can also induce active functional groups on polymeric PCL chains, and by reacting with a variety of biological molecules such as proteins or peptides it can accumulate at the scaffold ${ }^{[26]}$. Also, adding some functional groups such as HA to the scaffold substrate increases the absorption of proprietary proteins. By adding HA particles to the scaffold surface, specific proteins are absorbed, including fibronectin and osteocalcin, and the scaffold ability increases the proliferation and differentiation of MC3T3-E1 cells into the bone ${ }^{[27]}$.

The properties of materials are determined by their structure, and nano-composites exhibit better properties due to their structural changes, and results have shown that these properties are due to hydrogen bonding between the functional groups of PCL and HA. The hydrogen bond is a weak bond between two molecules resulting from an electrostatic attraction between a proton in one molecule and an electronegative atom in the other. This transplant, which plays an important role, is in many biochemical reactions and determines the properties of the material ${ }^{[28]}$. Hydroxyapatite has hydrophilic properties; therefore, the presence of HA in the scaffold can significantly increase the water absorption of the PCL/nHA scaffolds ${ }^{[29]}$. As shown in the results, HA particles at the scaffold surface increased the scaffold hydrophilic properties by increasing the hydroxyl group in the scaffold, and the hydrophilic scaffold could then provide a more favorable environment for cellular connectivity and growth.

Porosity is one of the important parameters in tissue engineering. Porosity above $80 \%$ is considered ideal for scaffolds $^{[30]}$. The results of the porosity measurements in this study indicate a decrease in porosity in composite scaffolds. By increasing the percentage of HA in composite scaffolds, porosity decreased, which was caused by the accumulation of HA particles in the cavities of the scaffolds. However, in all scaffolds with a different HA ratio (10\% to $50 \%$ ), the porosity was above $80 \%{ }^{[31]}$. As noted above, the scaffolds produced by this method have porosities greater than $90 \%$ being related to each other. Apparently, due to the lower concentration of HA nanoparticles compared to the scaffold prepared by Sui[ ${ }^{[32]}$, and also the appropriate solvents used in the present study, HA had no significant effect on the porosity of the composite scaffold than the scaffold alone.

Another very important feature of the scaffolds in this research is the size of porosity that was created. The size of the scaffold pores should be within the range that allows the transfer, penetration, and migration of the cell. On the other hand, they should not be so large that they reduce the possibility of interacting with the scaffold ${ }^{[33]}$.

Moreover, the communication of the pore with each other in all directions was another important point in the current study, such that in addition to the two-dimensional communication of the cell and the scaffold, it created the possibility of 3-D cellular communication with the scaffolds and other cells. This issue is important in bone tissue engineering and achieving this amount of porosity is one of the unique features of the present study.

To confirm the physical and chemical interactions, the ATR-FTIR analysis was performed and the presence of the absorption peak associated with the $\mathrm{C}=\mathrm{O}$ and $\mathrm{OH}$ groups was confirmed by the presence of a hydrogen bond between them. On the other hand, the presence of the peak pore of the $\mathrm{PO}_{4}$ group was due to the presence of a nanoparticle $\mathrm{HA}$ is at the level of the fiber.

The cell source used in this study was WJ-MSCs. These cells are a component of the multipotent stem cells ${ }^{[30]}$. A major issue in adult stem cell studies is the lack of 
quick and easy access to cell sources, and in obtaining an acceptable number of cells. Hence, a part of this study is on how to isolate mesenchymal stem cells and the concentrated amount of cellular efficiency of the source of these cells. Mesenchymal stem cells are highly accessible, have a low cost, and are culturally expandable in vitro compared to other sources, such as bone marrow, fat tissue, and so on ${ }^{[34]}$. Wharton Jelly is located between three different sections of the umbilical cord, the perivascular, intravascular, and sub amniotic. Separation of the cell from the umbilical cord occurs by both enzymatic and non-enzymatic methods. In this study, because of the low cost and its reliability, the non-enzymatic method was used ${ }^{[7]}$.

Several studies have shown that CD51, CD29, CD44, CD105, CD73, and CD90 markers are present in umbilical mesenchymal cells ${ }^{[35,36]}$. In this study, the presence of CD105 and CD90 markers and absence of CD45 markers in the umbilical mesenchymal cells was confirmed by flow cytometry.

In the current study, electron microscope images confirmed the growth of Wharton's jelly-derived mesenchymal stem cells on the scaffolds. Based on the images, the cells have cytoplasmic frills and natural morphology, often found in the form of cellular colonies and they interact with adjacent cells. The results also showed that based on the morphology of the cells, in addition to being able to bind and reproduce in nanocomposites, they have natural conditions. In fact, the presence of nanoparticles at the scaffold level increased the absorption of fibronectin and vitronectin from the serum and it led to integral connections. Such integral connections induced the rearrangement of F-actin fibers in the cellular skeleton and increased the cellular response to specialized signals for proliferation and cellular differentiation ${ }^{[37]}$.

Diagrams from the MTT test on different days also showed suitable biocompatibility of the cells in the surface of the scaffolds. In general, the results of the MTT test showed that by increasing the time to day 7 , the viability of cells increased significantly compared to days 3 and 5. On the other hand, some studies have shown HA particles cause rough surfaces and roughness in the scaffolds that cause suitable adhesion of the cells on the scaffolds. However, in the present study it is possible that the magnitude of the presence of HA at the scaffold surface had a positive effect on cellular binding.

In this study, the pattern of differentiation of umbilical mesenchymal stem cells into osteoblast cells was compared on the scaffolds. One of the changes that were observed in differentiated cells into osteoblasts, was calcium sedimentation in these cells, which even at high densities, bone nodules were formed ${ }^{[38]}$. In this study, the alizarin red staining converted calcium deposits into red. The differentiation of cells into osteoblasts was confirmed after 7, 14, and 21 days of treatment. Also, von Kossa coloring on day 21 showed differentiation of the amount of calcium deposits; however, staining the cells that were treated with normal medium for 21 days did not show calcium sedimentation. Comparison of the coloring results showed a high degree of differentiation in composite scaffolds compared to single scaffolds and cellular samples.

\section{CONCLUSION}

WJ-MSCs at the surface of the PCL/HA10\% composite scaffold show a greater degree of osteogenic differentiation. Hence, it seems, PCL/HA10\% composite scaffolds are suitable candidates for bone tissue engineering.

\section{ACKNOWLEDGEMENTS}

We are grateful for the help and financial support of Urmia University in this study.

\section{CONFLICTS OF INTEREST}

There are no conflict of interest

\section{REFERENCE}

1. Hollinger JO, Einhorn TA, Doll B, Sfeir C, editors Bone tissue engineering. CRC press; 2004.

2. Roseti L, Parisi V, Petretta M, Cavallo C, Desando $\mathrm{G}$, Bartolotti I, et al. Scaffolds for bone tissue engineering: state of the art and new perspectives. Materials Science and Engineering: C. 2017; 78:1246-62. doi: 10.1016/j.msec.2017.05.017.

3. Webber MJ, Khan OF, Sydlik SA, Tang BC, Langer R. A perspective on the clinical translation of scaffolds for tissue engineering. Annals of biomedical engineering. 2015; 43(3):641-56. doi: 10.1007/s10439-014-1104-7.

4. Deb P, Deoghare AB, Borah A, Barua E, Lala SD. Scaffold Development Using Biomaterials: A Review. Materials Today: Proceedings. 2018; 5(5):12909-19. doi: 10.1016/j.matpr.2018.02.276.

5. Christou I, Mallis P, Michalopoulos E, Chatzistamatiou T, Mermelekas G, Zoidakis $\mathrm{J}$, et al. Evaluation of Peripheral Blood and Cord Blood Platelet Lysates in Isolation and Expansion of Multipotent Mesenchymal Stromal Cells. Bioengineering. 2018; 5(1):19. doi: 10.3390/bioengineering5010019.

6. Kargozar S, Mozafari M, Hashemian SJ, Brouki Milan P, Hamzehlou S, Soleimani M, et al. Osteogenic potential of stem cells-seeded bioactive nanocomposite scaffolds: A comparative study between human mesenchymal stem cells derived from bone, umbilical cord Wharton's jelly, and adipose tissue. Journal of Biomedical Materials Research Part B: Applied Biomaterials 2018; 106(1):61-72. doi: 10.1002/jbm.b.33814.

7. Davies JE, Walker JT, Keating A. Concise Review: Wharton's Jelly: the rich, but enigmatic, source of mesenchymal stromal cells. Stem cells translational medicine. 2017; 6(7):1620-30. doi: 10.1002/sctm.16-0492. 
8. White JL, Walker NJ, Hu JC, Borjesson DL, Athanasiou KA. A comparison of bone marrow and cord blood mesenchymal stem cells for cartilage self-assembly. Tissue Engineering Part A. 2018; 24(15-16):1262-1272. doi: 10.1089/ten.TEA.2017.0424.

9. Hum J, Naseri S, Boccaccini AR. Bioactive glass combined with zein as composite material for the application in bone tissue engineering. Biomedical Glasses. 2018; 4(1):72-81. doi:10.1515/bglass-2018-0007.

10. Dash TK, Konkimalla VB. Poly- $\epsilon-$ caprolactone based formulations for drug delivery and tissue engineering: A review. Journal of Controlled Release. 2012; 158(1):15-33. doi: 10.1016/j.jconrel.2011.09.064.

11. Salgado CL, Sanchez EM, Zavaglia CA, Granja PL. Biocompatibility and biodegradation of polycaprolactone-sebacic acid blended gels. Journal of Biomedical Materials Research Part A. 2012; 100(1):243-51. doi: 10.1002/jbm.a.33272.

12. Lai $\mathrm{Y}$, Cao H, Wang X, Chen S, Zhang M, Wang $\mathrm{N}$, et al. Porous composite scaffold incorporating osteogenic phytomolecule icariin for promoting skeletal regeneration in challenging osteonecrotic bone in rabbits. Biomaterials. 2018; 153:1-3. doi:10.1016/j.biomaterials.2017.10.025.

13. Carlin R, Davis D, Weiss M, Schultz B, Troyer D. Expression of early transcription factors Oct-4, Sox-2 and Nanog by porcine umbilical cord (PUC) matrix cells. Reproductive Biology and Endocrinology. 2006; 4(1):8. doi: 10.1186/1477-7827-4-8.

14. Gandhimathi C, Venugopal JR, Ramakrishna S, Srinivasan DK. Electrospun-electrosprayed hydroxyapatite nanostructured composites for bone tissue regeneration. Journal of Applied Polymer Science. 2018; 135(42):46756. doi:10.1002/app.46756.

15. Hou J, Fan D, Zhao L, Yu B, Su J, Wei $\mathrm{J}$, et al. Degradability, cytocompatibility, and osteogenesis of porous scaffolds of nanobredigite and PCL-PEG-PCL composite. International journal of nanomedicine. 2016; $11: 3545$.

doi: $10.2147 /$ IJN.S97063.

16. Przekora A, Palka K, Ginalska G. Biomedical potential of chitosan/HA and chitosan/ $\beta-1$, 3 -glucan/HA biomaterials as scaffolds for bone regeneration-A comparative study. Materials Science and Engineering: C. 2016; 58:891-9. doi: 10.1016/j.msec.2015.09.046.

17. Wang YW, Wu Q, Chen J, Chen GQ. Evaluation of three-dimensional scaffolds made of blends of hydroxyapatite and poly (3-hydroxybutyrate-co3-hydroxyhexanoate) for bone reconstruction. Biomaterials. 2005.26 (8): 899 - 904. doi: 10.1016/j.biomaterials.2004.03.035

18. Chen JP, Su CH. Surface modification of electrospun PLLA nanofibers by plasma treatment and cationized gelatin immobilization for cartilage tissue engineering. Acta biomaterialia. 2011; 7(1):234-43. doi: 10.1016/j.actbio.2010.08.015

19. Qiao, C., et al., Human mesenchymal stem cells isolated from the umbilical cord. Cell biology international, 2008. 32(1): p. 8-15. doi: 10.1016/j.cellbi.2007.08.002.

20. Secunda R, Vennila R, Mohanashankar AM, Rajasundari M, Jeswanth S, Surendran R. Isolation, expansion and characterisation of mesenchymal stem cells from human bone marrow, adipose tissue, umbilical cord blood and matrix: a comparative study. Cytotechnology. 2015; 67(5):793-807. doi: 10.1007/s10616-014-9718-z.

21. Spadaccio C, Rainer A, Trombetta M, Vadala G, Chello M, Covino E, et al. Poly-L-lactic acid/ hydroxyapatite electrospun nanocomposites induce chondrogenic differentiation of human MSC. Annals of biomedical engineering. 2009; 37(7):1376-89. doi: 10.1007/s10439-009-9704-3.

22. Angius F, Floris A. Liposomes and MTT cell viability assay: an incompatible affair. Toxicology in Vitro. 2015; 29(2):314-9. doi: 10.1016/j.tiv.2014.11.009.

23. Pittenger MF, Mackay AM, Beck SC, Jaiswal RK, Douglas R, Mosca JD, et al. Multilineage potential of adult human mesenchymal stem cells. Science. 1999; 284(5411):143-7. doi: $10.1126 /$ science. 284.5411 .143 .

24. Chen W, Liu X, Chen Q, Bao C, Zhao L, Zhu Z, et al. Angiogenic and osteogenic regeneration in rats via calcium phosphate scaffold and endothelial cell co-culture with human bone marrow mesenchymal stem cells (MSCs), human umbilical cord MSCs, human induced pluripotent stem cell-derived MSCs and human embryonic stem cell-derived MSCs. Journal of tissue engineering and regenerative medicine. 2018; 12(1):191-203. doi: 10.1002/term.2395.

25. De Witte TM, Fratila-Apachitei LE, Zadpoor AA, Peppas NA. Bone tissue engineering via growth factor delivery: from scaffolds to complex matrices. Regenerative biomaterials. 2018; 5(4):197-211. doi: $10.1093 / \mathrm{rb} / \mathrm{rby} 013$.

26. Armentano I, Tarpani L, Morena F, Martino S, Latterini L, Torre L. Nanostructured biopolymerbased materials for regenerative medicine applications. Current Organic Chemistry. 2018; 22(12):1193-204. doi: 10.2174/13852728226661 


\section{1.}

27. Goddard JM, Hotchkiss JH. Polymer surface modification for the attachment of bioactive compounds. Progress in polymer science. 2007; 32(7):698-725. doi: 10.1016/j.progpolymsci.2007.04.002.

28. Mirza S, Zia I, Jolly R, Kazmi S, Owais M, Shakir M. Synergistic combination of natural bioadhesive bael fruit gum and chitosan/nanohydroxyapatite: A ternary bioactive nanohybrid for bone tissue engineering. International journal of biological macromolecules. 2018; 119:215-24. doi: 10.1016/j.ijbiomac.2018.07.128.

29. Casanova MR, Reis RL, Martins A, Neves NM. The Use of Electrospinning Technique on Osteochondral Tissue Engineering. Osteochondral Tissue Engineering: Nanotechnology, ScaffoldingRelated Developments and Translation. 2018:24763. doi: 10.1007/978-3-319-76711-611.

30. Nagail A, Horiuchiz N, Nozakiz K, Nakamuraz M, YamashitaZ K. Quantitative Evaluation of the Hydrophilic Properties of Polarized Hydroxyapatite. Biomaterials Science: Processing, Properties and Applications III: Ceramic Transactions. 2013; 242:103-11. doi: 10.1002/9781118751015.ch12.

31. Tangsadthakun C, Kanokpanont S, Sanchavanakit $\mathrm{N}$, Pichyangkura $\mathrm{R}$, Banaprasert $\mathrm{T}$, et al. The influence of molecular weight of chitosan on the physical and biological properties of collagen/ chitosan scaffolds. Journal of Biomaterials Science, Polymer Edition. 2007 Jan 1; 18(2):14763. doi: $10.1163 / 156856207779116694$.

32. Sui, G., et al., Poly-L-lactic acid/hydroxyapatite hybrid membrane for bone tissue regeneration Journal of Biomedical Materials Research Part A, 2007. 82(2): p. 445-454. doi: 10.1002/jbm.a.31166.

33. Pavia FC, Conoscenti G, Greco S, La Carrubba V, Ghersi G, Brucato V. Preparation, characterization and in vitro test of composites poly-lactic acid/hydroxyapatite scaffolds for bone tissue engineering. International journal of biological macromolecules. 2018; 119:945-53. doi: 10.1016/j.ijbiomac.2018.08.007.

34. Rebovich M. Electrospinning poly (lactic acid) with a bimodal inter-fiber pore size distribution: Cornell University; 2010.

35. Hielscher D, Kaebisch C, Braun BJ, Gray K, Tobiasch E. Stem Cell Sources and Graft Material for Vascular Tissue Engineering. Stem Cell Reviews and Reports. 2018:1-26. doi: 10.1007/s12015-018-9825-X.

36. Watson N, Divers R, Kedar R, Mehindru A, Mehindru A, Borlongan MC, Borlongan CV. Discarded Wharton jelly of the human umbilical cord: a viable source for mesenchymal stromal cells. Cytotherapy. 2015; 17(1):18-24. doi: 10.1016/j.jcyt.2014.08.009.

37. Heldring N, Mäger I, Wood MJ, Le Blanc $\mathrm{K}$, Andaloussi SE. Therapeutic potential of multipotent mesenchymal stromal cells and their extracellular vesicles. Human gene therapy. 2015; 26(8):506-17. doi: 10.1089/hum.2015.072.

38. Wang KX, Xu LL, Rui YF, Huang S, Lin SE, Xiong $\mathrm{JH}$, et al. The effects of secretion factors from umbilical cord derived mesenchymal stem cells on osteogenic differentiation of mesenchymal stem cells. PLoS One. 2015; 10(3). doi: 10.1371/journal.pone.0120593. 
الملخص العربى

\section{الخلايا الجذعية الوسيطة المشتقة من هلام وارتون وسقالة بولي كابرولاكتون / نانو

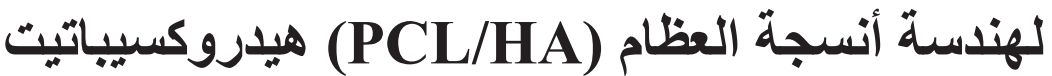

محمد رحماني'، محمد قاسم غل محمدي'، أسد الله أسدي، أمير دلاور؛، فرح فرخي'

'قسم الأحياء، كلية العلوم، جامعة أورمية، أورمية، إيران

بقسم التشريح، مختبر علم الأجنة والخلايا الجذعية، كلية الطب، جامعة أردبيل للعلوم الطبية، أردبيل، إيران "قسم الأحياء، كلية العلوم، جامعة محقق أردبيلي، أردبيل، إيران

قُسم التشريح وبيولوجيا الخلية، كلية الطب، جامعة مشهر للعلوم الطبية، مشهد، إيران

الخلفية: البوليكابرو لاكتون (PCL) هي بوليمر مناسب في مجال توصيل الأدوية و سقالات هندسة الأنسجة. هدف الاراسة: هذه الدراسة تهدف إلى تصميم سقالة هجينة من الألياف النانوية متعددة بولي كابرو لاكتون / نانو هيدروكسيباتيت ( • (PCL/nHA)و تقييم التمايز بين الخلايا الجذعية الوسيطة المشتقة من الهلام في وارتون إلى النسب العظمي على السقالات لهندسة أنسجة العظام. المواد والطرق: في هذه الدر اسة تم تحضير السقالات نانو البوليمرية المركبة ( • (PCL/nHA) عن طريق الغزل الكهربائي. تم عزل الخلايا الجذعية الوسيطة من جيلي وارنون و زرعت في سقالة (•PCL/nHA). التو افق الحيوي للسقالات بواسطة اختبار MTT. تم إجر اء توصيف الخلايا الجذعية الوسيطة للحبل السري باستخدام قياس التدفق الخلوي. تم إجر اء الخصاص المورفولوجيةو كيفية الالتصاق الخلوي للخلايا الجذعية الوسيطة (MSCs) على السقالات باستخدام التصوير بالمجهر الإلكتروني (SEM) و أخير ا عولجت الخلايا بوسيط تمايز عظمي المنشأ لمدة ا ب يوما للتحقق من إمكانات التمايز على السقالات ثم تلطخ الخلايا المتمايزة ببقع الأليز ارين الأحمر و فون كوسا.

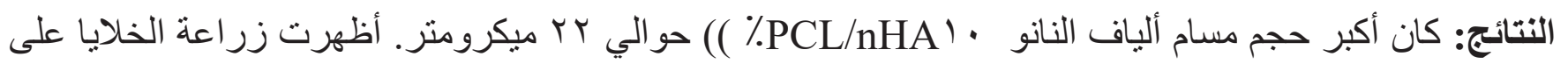
السقالات أن إضافة • • PCL إلى سقالة PCL تسبب المزيد من الارتباط و انتشار الخلايا. كما تمت مقارنة سقالة الرو اسب المعدنية الملطخة باللون الأليزارين الأحمر و فون كوسا. في كلا النوعين من التلوين، أظهرت السقالة المركبة النانوية ترسبات الكالسيوم أعلى. الخلاصة: أظهرت النتائج أن سقالات (·PCL /nHA ( لهندسة أنسجة العظام هي خيار جيد، ويمكن استخدامه لإصلاح أنسجة العظام 